\title{
Review
}

\section{Overview of Methods Used in the Diagnosis of Infectious Bursal Disease}

\author{
Kedir Sali, DVM (Student)* \\ College of Veterinary Medicine, Haramaya University, Haramaya, Ethiopia \\ "Corresponding author \\ Kedir Sali, DVM (Student) \\ College of Veterinary Medicine, Haramaya University, Haramaya, Ethiopia; E-mail: kedirsali@yahoo.com
}

\section{Article information}

Received: January $30^{\text {th }}$, 2019; Revised: March $3^{\text {rd }}$, 2019; Accepted: March 13 $3^{\text {th }}$, 2019; Published: April $1^{\text {st }}, 2019$

\section{Cite this article}

Sali K. Overview of methods used in the diagnosis of infectious bursal disease. Vet Med Open J. 2019; 4(I): 9-17. doi: |0.17| 40/VMOJ-4-|3।

\begin{abstract}
| ABSTRACT |
Infectious bursal disease (IBD) is an infectious viral disease of poultry. It is caused by infectious bursal disease virus (IBDV) that is a member of the genus Avibirnavirus of the family Birnaviridae. The virion is non-enveloped and consists of a bi-segmented RNA molecule. The disease occurs in a clinical and subclinical form depending on age at infection. Only young chickens are clinically affected. Severe acute disease of 3-6 week old birds is associated with high mortality but a less acute or subclinical disease is common in 0-3-week-old birds. This can cause secondary problems due to the effect of the virus on the bursa of Fabricius. There are two serotypes of IBDV; These are serotype 1 which is pathogenic to chickens and commonly leads to the development of the clinical form of the disease and serotype 2 is avirulent to chickens. Clinical IBD can be diagnosed by the combinations of a characteristic sign and post-mortem lesions. Gross lesions are characterized by marked haemorrhages in the pectoral and thigh muscles. At post-mortem examination bursa of Fabricius, thymus, spleen and kidneys are initially enlarged, however, bursa of Fabricius and thymus are later become atrophic. Histologic lesions showed marked edema, infiltration of heterophiles, hyperaemia and lymphoid depletion and hyper plastic corticomedullary layer in the bursa of Fabricius. Serological diagnosis of IBD by agar gel immunodiffusion (AGID), enzyme linked immunosorbent assay (ELISA), virus neutralization test (VNT) and agar gel precipitin test (AGPT) are also possible. Subclinical IBD can be confirmed in the laboratory by detecting viral antigens in tissues. In the absence of such tests, histological examination of the bursa may be helpful.

Keywords

Gross lesions; IBDV; Serology; Molecular techniques; Bursal disease; Gumboro disease.

\section{Abbreviations}

AGID: Agar gel immunodiffusion; AGPT: Agar Gel Precipitin Test; BF: Bursa Fabricius; CAM: Chorio Allantoic Membrane; CDNA: Complementary Deoxy Ribonucleic Acid; CEF: Chicken Embryo Fibroblast; CPE: Cyto-pathic effect; DsRNA: Double Stranded Ribonuclic Acid; ELISA: Enzyme linked immunosorbent assay; IBD: Infectious Bursal Disease; IBDV: Infectious Bursal Disease Virus; MDA: Maternally Derived Antibodies; ORF: Open Reading Frame; PMOLE: Picomole; SAN: Specific Antibody Negative; SPF: Specific Pathogen Free; VNT: Virus Neutralization Test.
\end{abstract}

\section{INTRODUCTION}

Tnfectious bursal disease is an acute and highly contagious disease 1 which is mostly affects young chickens of 3-6 weeks old. The disease, also named "Gumboro disease" according to the location of the first outbreaks in Gumboro, Delaware, USA, was initially described as avian nephrosis due to damage seen in the kidneys, ${ }^{1}$ but was later designated infectious bursal disease (IBD) according to varying morphologic and histological changes observed in the bursa of Fabricius. ${ }^{2}$

The causal agent of IBD is infectious bursal disease virus (IBDV), which is a non-enveloped double stranded RNA (dsRNA) virus belonging to the genus Avibirnavirus, family Birnaviridae. ${ }^{3-5}$ Infectious bursal disease virus genome has two double-stranded RNA segments; these are segment A and segment B. ${ }^{6}$ Segment A 
contains two partially overlapping open reading frames (ORFs), these are; ORF1 and ORF2. The small ORF1 encodes a non-structural protein VP5, whereas the large ORF2 encodes a precursor polyprotein (NH2-VP2- VP4-VP3-COOH), which is processed to produce mature protein like VP2, VP3 and VP4. The largest ORF contains a polyprotein that is proteolytically cleaved to form three polypeptides: namely VP2 and VP3 are the structural proteins, whereas VP4 is a protease. ${ }^{3,7}$ Segment B contains one ORF encoding VP1, ${ }^{7,8}$ with the multifunctional protein having the polymerase (an RNA-dependent RNA polymerase) that is responsible for viral genome replication, mRNA synthesis and capping enzymatic activity. ${ }^{9}$

The IBDV is one of the most economically important diseases that affect the growth of young chickens which results in significant economic losses in the poultry industry..$^{10}$ The virus has a selective tropism for actively dividing bursal B-lymphocytes which leads to massive destruction of B-lymphocytes in the bursa and to a lesser degree, in other lymphoid organs thereby causing prolonged immunosuppression of chickens infected before 3 weeks of age. ${ }^{11,12}$

Commonly young chickens at $0-2$ weeks old have a high level of maternally derived anti bodies (MDA) hence, resistance to IBD. Nevertheless, the MDA level declines with age and so also bursa of Fabricius. Once the target organ reaches its maximum development between 3 to 6 weeks, thereafter the chickens will be highly susceptible to IBD. ${ }^{13}$

Strains of IBDV can be grouped within two distinct serotypes by virus neutralization test. ${ }^{14}$ Serotype 1 is pathogenic in chickens and serotype 2 , isolated from turkeys, is not pathogenic in chickens or turkeys. ${ }^{6}$ Serotype 1 strains are further classified into very virulent $(\mathrm{VV})$, classical virulent, and sub-clinical on the basis of pathogenicity. ${ }^{15}$ Very virulent strains of serotype 1 IBDV are common worldwide and cause serious disease. Clinical IBD can be diagnosed by a combination of characteristic signs and post-mortem lesions. Subclinical IBD can be confirmed in the laboratory by demonstrating a humoral immune response in unvaccinated chickens, or by detecting viral antigens or viral genome in tissues. In the absence of such tests, histological examination of bursae may be helpful. ${ }^{16}$

Clinical IBD is responsible for heavy economic losses due to impaired growth, death and also from the excessive condemnation of carcasses because of skeletal muscle haemorrhages ${ }^{17,18}$ and losses due to immunosuppression. ${ }^{19}$ The clinical features of the IBD included whitish or watery diarrhoea, followed by anorexia, depression, trembling, severe prostration, and death. At necropsy, the birds exhibited dehydration, haemorrhages in the leg and thigh muscles, urate deposits in kidneys and enlargement of the bursa of Fabricius. ${ }^{20}$ Infectious bursal disease has not been reported to have any zoonotic potential. ${ }^{21}$

The infection, when not fatal, cause immunosuppression, in most cases temporary, depending on the virulence of the strain, the age, breed and the presence or absence of passive immunity. In chicken flocks, clinical picture and the course of the disease usually are indicative of an IBDV infection, and the pathological changes observed at the Bursa of fabricius (BF) are characteristic. ${ }^{13}$ Presence of this disease causes alterations in different haematological and serum biochemical parameters in poultry. ${ }^{18}$ The immunosuppressive effects of IBDV infections enhance the chicken's susceptibility to secondary bacterial infections such as gangrenous dermatitis, Escherichia coli infections, with a viral infection like chicken anemia agent, inclusion body hepatitis, respiratory diseases. ${ }^{11}$

Therefore, the objective of this paper is to highlight various commonly used diagnostic techniques of IBD.

\section{DIAGNOSIS OF INFECTIOUS BURSAL DISEASE |}

Infectious Bursal Disease is diagnosed by considering the flock's history and of the clinical signs and post mortem lesions. Obviously, chickens less than 3 weeks of age present no clinical signs of disease but chickens greater than 3 weeks of age present clinical signs. ${ }^{22}$ Clinical manifestations and postmortem findings of affected birds may aid to diagnose a disease but laboratory diagnosis is necessary for confirmation of the diseases. ${ }^{23}$

Isolation and identification of the agent provide the most certain diagnosis of IBD but are not usually attempted for routine diagnostic purposes because the virus is difficult to isolate. In practice, laboratory diagnosis of IBD depends on detection of specific antibodies to the virus, or on detection of the virus antigen and nucleic acid in tissues, using immunological or molecular methods. ${ }^{16}$ Confirmatory diagnosis of IBDV is most commonly performed by serology using Enzyme linked immunosorbent assay (ELISA), Agar gel precipitin test (AGPT) and Virus neutralization test (VNT) of bursal sections. ${ }^{24}$

\section{Clinical Signs}

Infectious bursal disease virus has a short incubation period of 2-3 days and the infection generally last 5-7 days. One of the earliest sign of IBDV infection is the tendency for the bird to engage in vent picking. ${ }^{25}$

In a typical outbreak in 2- to 15-week-old chickens, some $10-20 \%$ of the flock may show sudden signs. Observing any signs is difficult during the very early stages. One of the earliest signs is whitish or watery diarrhoea, with vent feathers soiled by urinary material. This is followed by anorexia, depression, trembling, severe prostration, and death. ${ }^{26}$ The disease is manifested by debilitation, dehydration and development of depression with the swollen and bloodstained vent. ${ }^{27}$

\section{Differential Diagnosis}

The lesions and symptoms of coccidiosis are very similar to IBD. Similar to IBD in coccidiosis there are sudden onset, ruffled feathers bloody droppings but no bursal lesion. ${ }^{28}$ However, muscular 
haemorrhages and edema of bursa differentiate IBD from coccodiosis. Other diseases that resemble IBD are infectious bronchitis virus, haemorrhagic syndrome, Marek's disease. ${ }^{29}$

Quinn reported that if there are enlarged muscular haemorrhages and enlarged edematous or haemorrhagic cloacal bursas, it would suggest IBD, however, the involvement of cloacal bursa usually will distinguish IBD from other nephrosis causing condition. Marek's (causes bursal atrophy, but nerve lesion is very distinct and also marek's forms tumors). Haemorrhages syndrome (cause bursal muscular mucosal haemorrhage, but with no bursal lesion) is the usual manifestation of the diseases. ${ }^{28}$

Non-infectious disease like mycotoxins are causes of bursal atrophy. ${ }^{30}$ In aflatoxins there is a degeneration of both thymus and the bursa and trichothecenes generally depress lymphocytopoesis. High doses of zearalenon also cause decreased bursal weight. As in other species, steroidal anti inflammatory drug like, corticosteroids cause apoptosis and decrease the production of lymphocytes and smaller bursas can be occurred in animals that are in poor nutritional states or stressed from other reasons..$^{31,32}$

\section{Gross Lesions}

Changes in lymphoid organs are typical of the disease. The BF, which is the main target of the virus, undergoes major changes beginning at $3 \mathrm{~d}$ post-infection (PI) when it increases in size reaching twice the normal size by $4 \mathrm{~d}$ PI followed by atrophy, reaching one third of its original weight by $8 \mathrm{~d}$ PI. The increase in size is accompanied by a red coloration. ${ }^{33}$ Autopsies performed on birds that died during the acute phase (three to four days following infection) indicate hypertrophic, hyperaemic and oedematous bursas. The most severe cases are characterized by a major infection of the mucous membrane and a serous transudate, giving the bursal surface a yellowish colour. This appearance is often accompanied by petechial and haemorrhages. The affected birds are severely dehydrated, and many birds have hypertrophic and whitish kidneys containing deposits of urate crystals and cell debris. ${ }^{34}$

Haemorrhages in the pectoral muscles and thighs are frequently observed, probably due to a coagulation disorder. ${ }^{35}$ Office International des Epizootics ${ }^{16}$ stated that the bursae of chickens infected with virulent serotype 1 IBDV appeared yellowish (sometimes haemorrhagic) with black cherry appearance and turgid, with prominent striations (Figures 1 and 2).

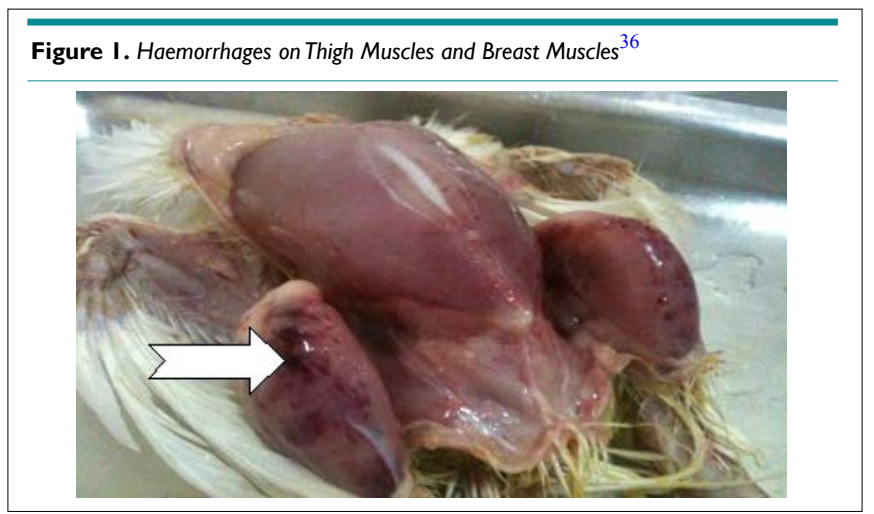

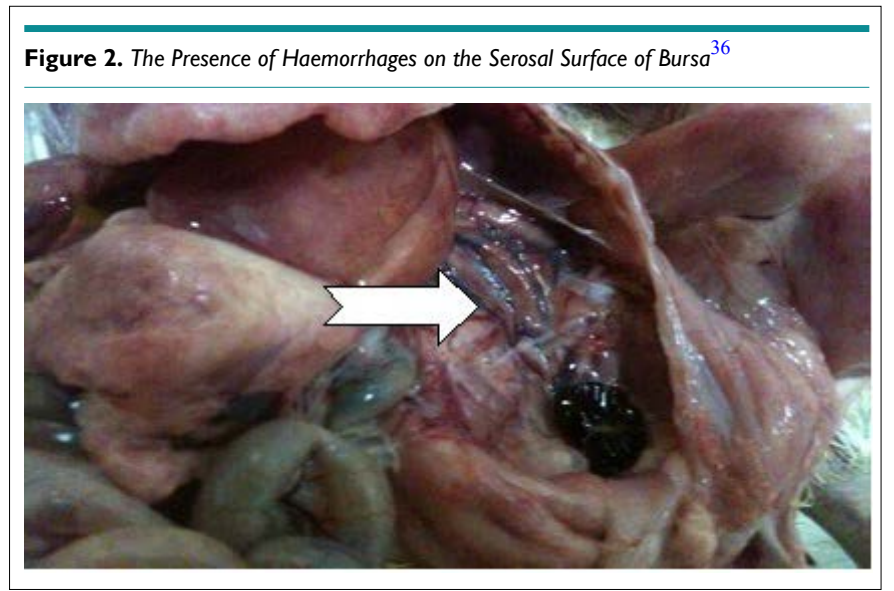

\section{Histopathological Lesions}

According to OIE, ${ }^{16}$ tissue of bursa of fabricius was removed aseptically from affected chickens in the early stages of the disease. Bursae is Chopped by using two scalpels, add a small amount of peptone broth containing penicillin and streptomycin $(1000 \mu \mathrm{g} / \mathrm{ml}$ each), and homogenise in a tissue blender. The homogenate is centrifuged at $3000 \mathrm{~g}$ for 10 minutes. Harvest the supernatant fluid for use in the investigations. The bursal tissue are fixed by immersion in $10 \%$ buffered formalin and processed for histologic examination by standard methods of paraffin embedding, sectioning and haematoxylin and eosin staining. ${ }^{37}$ The tissue sections were examined by light microscope and the severity of lesions was graded on the basis of the extent of lymphocyte necrosis, follicular depletion and atrophy. ${ }^{38}$

Histological diagnosis is based on the detection of modifications occurring in the bursa. The ability to cause histological lesions in the non-bursal lymphoid organs, such as the thymus, ${ }^{10}$ the spleen or bone marrow ${ }^{39}$ has been reported as a potential characteristic of hypervirulent IBDV strains.

Necrosis and infiltration of heterophils and plasma cells occur within the follicle, as well as, the interfollicular connective tissue. In addition, a fibroplasia, the inter follicular connective tissue, may appear and the surface epithelium of the bursa becomes involutes and abnormal. ${ }^{40}$ Histological lesions in the kidney are nonspecific and probably occur because of severe dehydration of affected chickens. Lesions observed consisted of large casts of homogeneous material infiltrated with heterophils, and also glomerular hypercellularity. ${ }^{11}$ Proliferation of the bursal epithelial layer generates a glandular structure of columnar epithelial cells that contains globules of mucin. During this stage of the infection, scattered foci of repopulating lymphocytes were observed; however, these did not develop into healthy follicles. ${ }^{41}$

\section{Virological Diagnosis}

In the acute phase of infection, Infectious bursal disease virus may be detected in the bursa of Fabricius of chicks ideally within the first three days following the appearance of clinical signs. ${ }^{34}$ 


\section{Virus Isolation in Cell Culture}

In order to observe cytopathic effect, $0.5 \mathrm{ml}$ of sample is inoculated into each of four freshly confluent chicken embryo fibroblast (CEF) cultures (from a specific pathogen free (SPF) source) in $25 \mathrm{~cm}^{2}$ flasks. Adsorb at $37{ }^{\circ} \mathrm{C}$ for $30-60$ minutes, wash twice with Earle's balanced salt solution and add maintenance medium to each flask. Then it is Incubated at $37{ }^{\circ} \mathrm{C}$, observing daily for evidence of cytopathic effect (CPE). This is characterized by small round refractive cells. If no CPE is observed after 6 days, discard the medium, then freeze-thaw the cultures and inoculate the resulting lysate into fresh cultures. The more pathogenic IBDV strains usually cannot be adapted to grow in CEF unless the virus has first been submitted to extensive serial passage in embryos. ${ }^{16}$

Cell cultures containing 50\% bursal lymphocytes and $50 \%$ CEF have been used to isolate and serotype IBD virus successfully. ${ }^{29}$ The traditional isolation method for IBDV using the chorioallantoic membrane of 9 to 11-day-old chicken embryos is no longer reliable, as some variant strains of the virus cause no embryo mortality. ${ }^{42}$ In addition, most field isolates cannot be readily adapted to grow in primary chicken cell cultures. ${ }^{43,44}$ However, embryo- or cell-culture adapted strains of IBDV replicate and produce cytopathic CPE in the avian continuous cell line ${ }^{45}$ and in mammalian continuous cell lines such as rabbit RK-13 cells ${ }^{46}$ and monkey Vero cells. ${ }^{47}$ Such cell lines provide sensitive media for assay of the virus. ${ }^{48,49}$

\section{Virus Isolation in Embryos}

To identify serotype 1 and serotype 2 inoculate $0.2 \mathrm{ml}$ of sample into the yolk sac of five 6- to 8-day-old specific antibody negative (SAN) chicken embryos and on to the chorioallantoic membrane of five 9 to 11 day-old SAN chicken embryos. Specific antibody negative embryos are derived from flocks shown to be serologically negative to IBDV. Candle daily and discard dead embryos up to 48 hours post-inoculation. Embryos that die after this time are examined for lesions. Serotype 1 IBD produces dwarfing of the embryo, subcutaneous oedema, congestion and subcutaneous or intracranial haemorrhages but Serotype 2 IBDV does not induce subcutaneous oedema or haemorrhages in the infected embryos, but embryos are of a smaller size with a pale yellowish discolouration. $^{16}$

Viral isolation was performed on bursas from infected chickens. Bursal tissue homogenate was inoculated onto the chorioallantoic membrane (CAM) of 10-day-old SPF embryonating chicken eggs. ${ }^{30}$

\section{Serological Diagnosis}

For serological investigations, usually blood can collected collect from the wing vein, allowed to clot and serum separated by centrifugation and stored at $-20{ }^{\circ} \mathrm{C}$ until tested. ${ }^{50}$ Serological tests generally used for the detection of IBDV are ELISA, VN and Agar Gel Immunodiffusion (AGID). The ELISA is the most commonly used test for the detection of antibodies to IBDV. ${ }^{29}$ The infection usually spreads rapidly within a flock of birds. Because of this, only a small percentage of the flock needs to be tested to detect the presence of antibodies. If positive reactions are found in unvaccinated birds then the whole flock must be regarded as infected. ${ }^{51}$

\section{Agar Gel Immunodiffusion (AGID)}

Agar gel immunodiffusion test is one of the alternative tests recommended for IBD diagnosis by Organisation for Animal Health (OIE) in its list of tests for international trade. ${ }^{52}$ The AGID test is the most useful of the serological tests for the detection of specific antibodies in sera, or for detecting viral antigen or antibodies in bursal tissue. Blood samples should be taken early in the course of the disease, and repeat samples should be taken 3 weeks later. Because the virus spreads rapidly, only a small proportion of the flock needs to be sampled. Usually 20 blood samples are enough. For detection of antigen in the bursa of Fabricius, the bursae should be removed aseptically from about ten chickens at the acute stage of infection. The bursae are minced using two scalpels in a scissor movement, and then small pieces are placed in the wells of the AGID plate against known positive serum. Freeze-thaw cycles of the minced tissue may improve the release of IBDV antigens from the infected bursal tissue. ${ }^{51}$

The result of tested serum is interpreted as when a clear precipitin line is formed a "line of identity" with that of the positive control antiserum and with the antigen in the central well but, when no line is formed the tested sera is considered as negative result. The test is repeated when no clear precipitin line is formed at the positive control well or when a suspicious reaction at the tested serum well observed. ${ }^{53}$

AGID is the simplest, but least sensitive technique. Results are obtained after an incubation period of $48 \mathrm{~h}$. Variability in results may be due to the investigator, as well as the nature of the viral strain used as an antigen..$^{5-58}$

The AGID test can also be used to measure antibody levels by using dilutions of serum in the test wells and taking the titre as the highest dilution to produce a precipitin line. ${ }^{59}$ This can be useful for measuring maternal or vaccinal antibodies and for deciding on the best time for vaccination; however, this AGID quantitative determination has now been largely replaced by the ELISA. ${ }^{60}$

\section{Enzyme Linked Immunosorbent Assay (ELISA)}

The principle of ELISA is that antibodies are attached to their specific antigen by linking an enzyme to an antibody following the addition of the substrate. A serum sample is added and if there are specific antibodies they will bind to the antigen. If there is a positive sample, the antibody will attach and react with the substrate. ${ }^{61}$ Thus the positive samples will develop colour. ${ }^{62,63}$

The ELISA allows the quantification of antibodies to IBDV and is therefore used for monitoring the immune status of 
the chicken flocks to check response to vaccination, natural field exposure and decay of maternal antibody titer. ${ }^{64}$ The ELISA is the most rapid and sensitive method and presents the fewest variations due to the viral strain used as an antigen. It is economical, simple, and quick and tests a large number of samples at the same time and is adaptive to automation to computer software. ${ }^{64}$ However, ELISA cannot differentiate between the antibodies specific to the two serotypes. ${ }^{64,65}$

\section{Agar Gel Precipitation Test (AGPT)}

Another method used to detect antibodies to IBDV is the AGP test. This test has been adapted to the quantitative format. ${ }^{59}$ Antigen was prepared from a saline suspension of bursae from chickens infected with IBD virus. Briefly, a 50\% suspension was homogenized and then clarified by centrifugation. The antigen was checked for sensitivity and specificity against known positive and negative sera but was not standardized otherwise. Test sera were placed in wells adjacent to positive control sera to enhance sensitivity and to establish specificity of lines. ${ }^{54}$

It is rapid but insensitive. It does not detect serotypic differences and measures primarily group-specific soluble antigens. ${ }^{64}$

\section{Virus Neutralization Test (VNT)}

In virus neutralization neutralization test (VNT) is the gold test and the only serologic test that discriminates between antibodies elicited by the two serotypes and various subtypes of the serotype 1 strains. $^{66}$

$\mathrm{VN}$ tests are carried out in cell culture. The test is more laborious and expensive than the AGID test, but is more sensitive for detecting antibody. This sensitivity is not required for routine diagnostic purposes, but may be useful for evaluating vaccine responses or for differentiating between IBDV 1 and 2 serotypes. ${ }^{51}$

When a virus is mixed with homologous antiserum it will be neutralized and not infectious. This is the principle of a VNT and can be visualized in cell cultures. If the virus usually produces a CPE in cell culture, the neutralized virus will not be able to produce it and thereby the effect of the serum can be observed. ${ }^{61}$

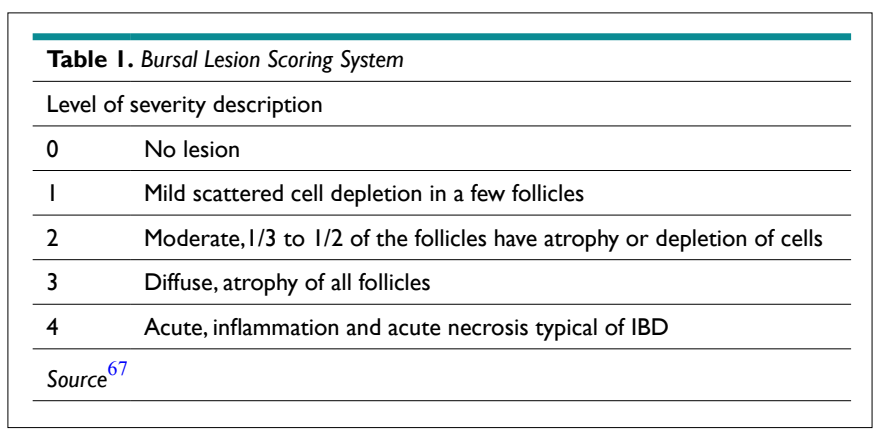

\section{Molecular Diagnosis of IBD}

Another method that is used to detect IBDV is molecular tech- nique. Reverse-Transcription Polymerase Chain Reaction (RTPCR) is one of the most important frequently used molecular method that is used to detect the genome of IBDV. ${ }^{68}$ Reverse transcription-polymerase chain reaction (RT-PCR) enable us to detect viral RNA in homogenates of infected organs or embryos, as well as in cell cultures, without considering the viability of the virus present. ${ }^{34}$ It is also used to detect the genome of viruses that don't replicate in cell culture because it doesn't require the growth of the virus before amplification. There are three steps in which RT-PCR is performed .These are; extraction of nucleic acids from studied sample, change of IBDV RNA into cDNA by Reverse Transcription (RT) and amplification of cDNA by PCR. The IBDV double stranded RNA stranded RNA (dsRNA) can't be degraded by RNAases, unlike single stranded RNA. ${ }^{69}$

\section{Extraction of IBDV RNA}

Infectious bursal disease RNA can be extracted from infected tissues by using some kits which is available from commercial suppliers of molecular biology reagent. In another way IBDV RNA can be extracted by adding $1 \%$ sodium dodecyl sulphate and $1 \mathrm{gm} / \mathrm{ml}$ proteinase $\mathrm{K}$ to $700 \mu \mathrm{l}$ of bursal homogenate and Incubated for 60 minutes at $37^{\circ} \mathrm{C}$. Nucleic acids are harvested from the final aqueous phase by ethanol precipitation and are resuspended in RNasefree distilled water or a suitable buffer. Water-diluted RNA should be kept frozen at a temperature below $-20{ }^{\circ} \mathrm{C}$ until use. ${ }^{69}$

\section{First Strand cDNA Synthesis}

The extracted RNA is used for the synthesis of cDNA. The following reagents are mixed in PCR tubes to a final volume of 25 $\mu \mathrm{L}$. These are; Template RNA $1 \mu \mathrm{g}$, OligodT primer $1 \mu \mathrm{L}$ and Nuclease free water to $12 \mu \mathrm{L}$. Then the above mixture was kept at $65^{\circ} \mathrm{C}$ for $5 \mathrm{~min}$ in a thermal cycler, followed by the addition of the following components in the indicated order: $5 \mathrm{X}$ reaction buffer $4 \mu \mathrm{L}$, Rnase inhibitor $1 \mu \mathrm{L}, 10 \mathrm{mM}$ dNTP $2 \mu \mathrm{L}$ and Reverse transcriptase $1 \mu \mathrm{L}$. The above mixture was kept at $42{ }^{\circ} \mathrm{C}$ for one hour and 5 minutes at $70{ }^{\circ} \mathrm{C}$ in a thermal cycler. ${ }^{70}$ Synthesized cDNA was used as template for polymerase chain reaction (PCR). ${ }^{71}$

\section{Reverse Transcriptase -Polymerase Chain Reaction (RT-PCR)}

The cDNA was amplified in a $25 \mathrm{ml}$ reaction mixture as given as below; Mastermix 12.5 $\mu \mathrm{L}$, Forward primer (20pmol) 5'-GGTAACYGTCCTCAGCT'TA-3' $1 \mu \mathrm{L}$, Reverse primer (20 pmol) 5'-GTTCAGGATTTGGGGATCAGC-3' $1 \mu \mathrm{L}$, Template DNA 3 $\mu \mathrm{L}$ and Nuclease-free water $7.5 \mu \mathrm{L}$. After amplified the reaction mixture was subjected to initial denaturation of $95^{\circ} \mathrm{C}$ for 5 minutes followed by 35 amplification cycles at $95{ }^{\circ} \mathrm{C}$ for 45 seconds, $51^{\circ} \mathrm{C}$ for 45 seconds and $72{ }^{\circ} \mathrm{C}$ for 1.30 minutes with final extension at $72{ }^{\circ} \mathrm{C}$ for 10 minutes. $^{70}$

The extracted RNA is changed into cDNA then RTPCR. Reverse Transcription-Polymerase chain reaction is work on VP2. The VP2 is the major structural protein that contains the antigenic regions responsible for the production of neutralizing antibodies in the chicken. VP2 contains a hypervariable region that 
displays the greatest amount of amino acid sequence variation between strains. ${ }^{72,73}$ This region is responsible for antigenic variation, tissue-culture adaptation and it is partially responsible for viral virulence. $^{74}$

A commercial cDNA synthesis kit (Fermantas, USA) is used to make cDNA. Hair-Bejo $\mathrm{M}^{4}$ also reported that for amplification of a 743 bp fragment of VP2 hypervariable region, two region, two primers are used these are; forward primer 5'-GCCCAGAGTCTACACCAT-3 and Reverse primer s5'-CCCGGATTATGTCTTTGA-3'. Then the amplification products were detected by gel electrophoresis in 1.5\% agarose gel in buffer. Gels were run for $1.5 \mathrm{~h}$ at $80 \mathrm{~V}$, stained with ethidium bromide $(0.5$ $\mu \mathrm{g} / \mathrm{ml}$ ), exposed to ultraviolet light and photographed (Visi-DocIt system, UVP, UK).

If four amino acids (alanine 222, isoleucine 256, isoleucine 294 and serine 299) are present simultaneously present, it simultaneously, it is considered as indicative of vvIBDV. ${ }^{75,76}$

\section{CONCLUSION AND RECCOMMENDATIONS}

Infectious bursal disease is one of the viral diseases that affect poultry all over the world. It mainly affects young chickens between 3-6 weeks old. This disease is highly affects bursa of Fabricius. Economic losses due to IBD is directly associated with mortality and in directly with immunosuppression. Infectious bursal disease is also called "gumboro disease" according to the location of first outbreaks in Gumboro Delaware, USA, was initially described avian nephrosis due to damage seen in kidney but later the name of avian nephrosis is changed to infectious bursal disease depending on morphologic and histologic change occurred in bursa of Fabricius. Infectious bursal disease virus is the highly contagious disease that causes IBD. Two serotypes are recognized. These are; serotype 1 which is pathogenic to chickens and serotype 2 which are not pathogenic to chickens. Diagnosis of IBD is depending on clinical signs, differential diagnosis, gross lesions, histopathological lesions, virus isolation, serological and molecular diagnosis. Agar gel immunodiffusion is the simplest but least sensitive where as ELISA is a rapid and sensitive method a rapid and sensitive method is but cannot differentiate serotypes. Virus neutralization test is the golden standard and the only serologic test that differentiate test that differentiates antibodies of two serotypes and sensitive but sensitive but it is more laborites laborious and expensive than AGID. Another method that is used to detect IBDV is molecular methods. Reverse Transcription-Polymerase Chain Reaction is used to detect IBDV without considering the viability of the virus by working on VP2 which is a major structural protein that is responsible for the production of neutralizing antibodies in chickens and it is a place where a greatest amount of amino acid variation occurred between strains. Depending on the above conclusion, the following recommendation is forwarded.

Early diagnosis of IBDV must be conducted because of it is highly contagious disease. Infectious bursal disease should be differentiated from other disease that has the same lesions. More sensitive and rapid test should be selected.

\section{ACKNOWLEDGEMENTS}

First, I would like to thank the almighty Allah, for giving me health, peace, love, energy and suitable condition throughout my life. Next I would like to passionately express my thankfulness to my advisors, Dr. Tesfaheywet Zeryehun.

Also, I wish to convey my sincere thanks to HUCVM library, computer and internet center staff for their kind operation.

\section{REFERENCES}

1. Cosgrove AS. An apparently new disease of chickens: Avian nephrosis. Avian Diseases. 1962; 6: 385-387. doi: 10.2307/1587909

2. Hitchner SB. Infectivity of infectious bursal disease virus for embryonating eggs. Poult Sci. 1970; 49: 511-513. doi: 10.3382/ ps.0490511

3. Bidin Z, Lojkic I, Grce M, Cajavec S, Pokric B. Differentiation of infectious bursal disease virus strains at a genomic level. Veterinarski Arbiv. 2001; 7: 325-336.

4. Hair-Bejo M, Ng MK, Ng HY. Day old vaccination against infectious bursal disease in broiler chickens. Int J Poult Sci. 2004; 3: 124-128. doi: 10.3923/ijps.2004.124.128

5. Pankhurst RT. Avian nephrosis (Gumboro disease) in USA broilers: Treatment trials. World's Poult Sci J. 1964; 20: 208-211. doi: 10.1079/WPS19640028

6. Mahgoub HA, Bailey M, Kaiser P. Erratum to: An overview of infectious bursal disease. Arch Virol. 2012; 12: 1377-1379. doi: 10.1007/s00705-012-1505-6

7. Delmas B, Mundt E, Vakharia VN, Wu JL. Family birnaviridae. In: King AMQ, Lefkowitz E, Adams MJ, Carstens EB (eds). Virus Toxonomy Ninth Report of the International Committee on Taxonomy of Viruses. San Diego, California, USA: Academic Press Inc. 2011. 507.

8. Berg TP. Acute infectious bursal disease in poultry: A review. Avian Pathol. 2000; 29: 175-194. doi: 10.1080/03079450050045431

9. Silva JV, Arenhart S, Santos HF, et al. Efficient assembly of fulllength infectious clone of Brazilian IBDV isolate by homologous recombination in yeast. BrazJ Microbiol. 2015; 45: 1555-1563.

10. Hussain I, Rasool MH, Mahmood MS. Production of hyperimmune serum against infectious bursal disease virus in rabbits. Pak Vet J. 2004; 24: 179-183.

11. Mahgoub HA. An overview of infectious bursal disease. Arch Virol. 2012; 157: 2047-2057. doi: 10.1007/s00705-012-1505-6 
12. Tanimura N, Sharma JM. Appearance of T cells in the bursa of fabricius and caecal tonsils during the acute phase of infectious bursal disease virus infection in chickens. Avian Dis. 1997; 41: 638645. doi: $10.2307 / 1592155$

13. Muller H, Islam MR, Raue R. Research on infectious bursal disease-the past, the present and the future. Vet Microbiol. 2003; 97: 153-165. doi: 10.1016/j.vetmic.2003.08.005

14. McFerran JB, McNulty MS, McKillop ER, et al. Isolation and serological studies with infectious bursal disease viruses from fowl, turkeys and ducks: Demonstration of a second serotype. Avian Pathol. 1980; 9: 395-400. doi: 10.1080/03079458008418423

15. Nwagbo IO, Shittu I, Nwosuh CI, et al. Molecular characterization of field infectious bursal disease virusisolates from Nigeria. Vet World. 2016; 9: 1420-1428. doi: 10.14202/vetworld.2016.1420-1428

16. Office International des Epizootics. Infectious bursal disease (gumboro disease). Rev Sci Tech. (Chap 2.3.12. 2016; 1). 2016; 551.

17. Lukert PD, Hitchner SB. Infectious bursal disease. In: Hofstad MS, Barnes HI, Calnek BW, Reid WM, Yoder HW (eds). Diseases of Poultry. $8^{\text {th }}$ (edn). Ames, Iowa, USA: Iowa State University Press. 1984. 566-576.

18. Tesfaheywet Z, Hair-Bejo M, Rasedee A. Hemorrhagic and clotting abnormalities in infectious bursal disease in specificpathogen-free chicks. World Appl Sci J. 2012; 16: 1123-1130.

19. Lukert PD, Saif YM. Infectious bursal disease. In: Calnek BW (ed). Diseases of Poultry. $10^{\text {th }}$ (edn), Ames, IOWA, USA: IOWA state university press. 1997. 721-738.

20. Hassan M, Al Natour MQ, Ward LA, Saif YM. Pathogenicity, attenuation, and immunogenicity of infectious bursal disease virus. Avian Dis. 1996; 40: 567-571. doi: 10.2307/1592265

21. Eterradossi N, Saif Y.M. Infectious bursal disease. In: Swayne DE (ed). Diseases of Poultry, $13^{\text {th }}$ (edn). Ames, Iowa, USA: John Wiley \& Sons Inc. 2013. 219-246.

22. Kegne T, Chanie M. Review on the incidence and pathology of infectious bursal disease. British Journal of Poultry Sciences. 2014; 3: 68-77. doi: 10.5829/idosi.bjps.2014.3.3.8556

23. Banda A. Characterization of Field Strains of Infectious Bursal Disease Virus (IBDV) Using Molecular Techniques [dissertation]. Athens, Georgia, USA: University of Georgia; 2002.

24. Jordan FTW, Pattison M. Poultry Diseases $4^{\text {th }}$ (ed). Philadelphia, USA: Saunders. 1996. 202.

25. Minalu T, Tewodros F, Bemrew A. Infectious bursal disease (GUMBORO disease) in chickens. Br J of Polt Sci. 2015; 4: 22-28. doi: 10.5829/idosi.bjps.2015.4.1.95172
26. Cosgrove AS. An apparently new disease of chickens: Avian nephrosis. Avian Diseases. 1962; 6: 388-389. doi: 10.2307/1587909

27. Islam MT, Samad MA. Clinico-pathological studies on natural and experimental infectious bursal disease in broiler chickens. Bangladesh Journal of Veterinary Medicine. 2014; 2: 31-35. doi: 10.3329/ bjvm.v2i1.1931

28. Kaufer I, Weiss E. Significance of bursa of Fabricius as target organ in infectious bursal disease of chickens. Infect Immun. 1980; 27: 364-367.

29. Lukert PD. Serotyping recent isolates of infectious bursal disease virus. Paper presented at: $123^{\text {rd }}$ Annual meeting of the american veterinary medical association; 1986; Kearney, NE, USA.

30. Swayne DE. A Laboratory Manual for the Isolation and Identification of Avian Pathogens, $4^{\text {th }}$ (edn), Kennett Square, PA, USA: the American Association of Avian Pathologists. 1998.

31. Farner DS, King JR, Parkes KC. Avian Biology. Cambridge, Massachusetts, USA: Academic Press Inc. 1983. 7.

32. Ridell C. Avian Histopathology. $2^{\text {nd }}$ (edn). Philadelphia, PA, USA: American Association of Avian Pathologists. University of Pennsylvania. 1996

33. Saif YM. Infectious bursal disease and hemorrhagic enteritis. Poult Sci. 1998; 77: 1186-1189. doi: 10.1093/ps/77.8.1186

34. Van den Berg TP, Eterradossi N, Toquin D Meulemans G. Infectious bursal disease (Gumboro disease). Rev sci tech Off int Epir. 2000; 19: 527-543.

35. Skeeles JK, Slavik M, Beasley JN, et al. An age-related coagulation disorder associated with experimental infection with infectious bursal disease virus. Am J vet Res. 1980; 41: 1458-1461.

36. Nawzad AR, Nahla MS, Shilan FM, Zana H Mahmood. Detection and identification of infectious bursal disease virus in broiler farms in sulaimani province. Int'l $J$ of Advances in Chemical Engg., \&BiolSci (IJACEBS). 2016; 3: 39-43. doi: 10.15242/ IJACEBS.A0316001

37. Tanimura N, Tsukamoto K, Nakamura K, Narita M, Maeda M. Association between pathogenicity of infectious bursal disease virus and viral antigen distribution detected by immunohistochemistry. Avian Dis. 1995; 39: 9-20. doi: 10.2307/1591976

38. Sreedevi B, LeFever LJ, Sommer-Wagner SE, Jackwood DJ. Characterization of infectious bursal disease viruses from four layer flocks in United States. Avian Dis. 2007; 51: 845-850. doi: 10.1637/7923-020607-REGR1.1

39. Inoue M, Fujita A, Maeda K. Lysis of myelocytes in chickens infected with infectious bursal disease virus. Vet Pathol. 1999; 36: 
146-151. doi: 10.1354/vp.36-2-146

40. Eterradossi N, Picault JP, Drouin P, Guittet M, L'Hospitalier R, Bennejean G. Pathogenicity and preliminary antigenic characterization of six infectious bursal disease vims strains isolated in France from acute outbreaks. J vet Med B. 1992; 39: 683-691. doi: 10.1111/j.1439-0450.1992.tb01222.x

41. Campbell TW, Coles EH. Avian clinical pathology. In: Coles EH (ed). Veterinary clinical pathology. Philadelphia, PA, USA: WB Saunders. 1986; 289-290.

42. Rosenberger JK, Cloud SS. Isolation and characterization of variant infectious bursal disease viruses. Paper presented at:. $123^{\text {rd }}$ Annual meeting of the american veterinary medical association; 1986; Kearney, NE, USA.

43. Lee LH, Lukert PD. Adaptation and antigenic variation of infectious bursal disease virus. J. Chin. Soc. Vet. Sci. 1986; 12: 297-304.

44. McFerran JB, McNulty MS, McKillop ER, et al. Isolation and serological studies with infectious bursal disease viruses from fowl, turkeys and ducks: Demonstration of a second serotype. Avian Pathol. 1980; 9: 401-400. doi: 10.1080/03079458008418423

45. Cowen BS, Braune MO. The propagation of avian viruses in a continuous cell line (QT35) of Japanese quail origin. Avian Dis. 1988; 32: 282-297. doi: 10.2307/1590815

46. Petek M, D’Aprile PN, Cancelloti F. Biological and physicochemical properties of the infectious bursal disease virus (IBDV). Avian Pathol. 1973; 2: 135-152. doi: 10.1080/03079457309353791

47. Lukert PD, Leonard J, Davis RB. Infectious bursal disease virus: Antigen production and immunity. Am J Vet Res. 1975; 36: 539-540.

48. Jackwood DH, Saif YM, Hughes JH. Replication of infectious bursal disease virus in continuous cell lines. Avian Dis. 1987; 31: 370-375. doi: 10.2307/1590888

49. Kibenge FS, Dhillon AS, Russel RG. Growth of serotypes I and II and variant strains of infectious bursal disease virus in vero cells. Avian Dis. 1988; 32: 298-303. doi: 10.2307/1590816

50. Shaimaa I, Mohamed MH, Mohga FB, et al. Effect of infectious bursal disease field vaccines on avian influenza vaccination immunity. Alexandria J of Vet Sci. 2014; 43: 33-36. doi: 10.5455/ ajvs. 162984

51. Office International des Epizooties. Infectious Bursal Disease (Gumboro disease). Chap 2.3.12. 2008; 549-565.

52. Office international des epizooties. Terrestrial manual list of tests for international trade. 2012; XI-XIV.

53. Chai YF. Biological and Molecular Characterisation and Crystallisation of Infectious Bursal Disease Virus and Its Major Capsid Protein. [dissertation]. Palmerston north, New Zealand: Turitea University; 2001.

54. Weisman J, Hitchner SB. Virus-neutralization versus agargel precipitin tests for detecting serological response to infectious bursal disease virus. Avian Dis. 1978; 22: 598-603. doi: $10.2307 / 1589634$

55. Wood GW, Muskett JC, Hebert CN, Thornton DH. Standardization of the quantitative agar gel precipitin test for antibodies to infectious bursal disease. J Biol Standard. 1979; 7: 89-96. doi: 10.1016/S0092-1157(79)80041-4

56. Wood GW, Muskett JC, Hebert CN, Thornton DH. The effect of antigen variation on the quantitative agar gel precipitin test for antibodies to infectious bursal disease virus. J Biol Stand., 1984; 12 : 311-314. doi: 10.1016/S0092-1157(84)80011-6

57. Nicholas RAJ, Reed NE, Wood GW, Hebert CN, Muskett JC, Thornton DH. Detection ofantibodies against infectious bursal disease: a comparison of three serological methods. Res vet Sci. 1985; 38: 189-192. doi: 10.1016/S0034-5288(18)31824-1

58. Van den Berg TP, Gonze M, Meulemans G. Acute infectious bursal disease in poultry: Isolation and characterisation of a highly virulent strain. Avian Pathol. 1991; 20: 133-143. doi: 10.1080/03079459108418748

59. Cullen GA, Wyeth PJ. Quantitation of antibodies to infectious bursal disease. Vet Rec. 1975; 97: 315. doi: 10.1136/vr.97.16.315-a

60. Office international des epizootics. Infectious bursal disease (gumboro disease). Chap: 2.3.12. 2. 2016; 2. 2016; 552.

61. Lindahl J. Infectious bronchitis virus and infectious bursal disease virus: A atudy performed at the universidad nacional of costa rica. 2004. 48.

62. Dinter Z. Diagnostic Virology. Moreno-Lopéz (ed). Uppsala, Sweden: University of agricultural sciences. 1989.

63. Stryer L. Biochemistry. $4^{\text {th }}$ (ed). New York, NY, USA: WH Freeman and Company. 1995.

64. Lukert PD, Saif YM. Infectious bursal disease. In: Saif YM, Barnes HJ, Fadly AM, Glisson JR, McDougald LR, Swayne DE (eds). Diseases of Poultry. 11 ${ }^{\text {th }}$ (ed). Ames, Iowa, USA: Iowa State Press. 2003. 161-179.

65. Hitchner SB. Infectivity of infectious bursal disease virus for embryonating eggs. Poult Sci. 1970; 49: 514-516. doi: 10.3382/ ps.0490511

66. Jackwood DH, Saif YM. Antigenic diversity of infectious bursal disease viruses. Avian Dis. 1987; 31: 766-770. doi: 10.2307/1591028

67. Skeeles JK, Lukert PD, Fletcher OJ, Leonard JD. Immunisation 
studies with a cell-culture-adapted infectious bursal virus. Avian Dis. 1979; 23: 456-465. doi: 10.2307/1589576

68. Lin Z, Kato A, Otaki Y, Nakamura T, Sasmaz E, Ueda S. Sequence comparisons of a highly virulent infectious bursal disease virus prevalent in Japan. Avian Dis. 1993; 37: 315-323. doi: $10.2307 / 1591655$

69. Office International des Epizooties. Infectious bursal disease (Gumboro disease). Chapter 2.3.12. In: OIE. Manual of Diagnostic Tests and Vaccines for Terrestrial Animals. Paris: Version adopted in May 2016. http://www.oie.int/en/internationalstandard-setting/ terrestrial-manual/accessonline/. 2016. 1-21.

70. Adamu JA, Owoade A, Abdu PA, Kazeem HM, Fatihu MY. 0 s. Characterization of field and vaccine infectious bursal disease viruses from Nigeria revealing possible virulence and regional markers in the VP2 minor hydrophilic peaks. Avian Pathol. 2013; 42: 420-433. doi: 10.1080/03079457.2013.822055

71. Rai Shafqat Ali Khan, Habib M, Muhammad Salah Ud Din Shah, et al. Molecular characterization of infectious bursal disease virus from commercial poultry in Pakistan. Matrix Science Medica. 2017; 1: 1-6.
72. Bayliss CD, Shaw K, Peters RW, et al. A comparison of sequences of segment $\mathrm{A}$ of four infectious bursal disease virus strains and identification of a variable region in VP2. J Gen Virol. 1990; 71: 1303-1312. doi: 10.1099/0022-1317-71-6-1303

73. Kibenge FS, Jackwood DJ, Mercade CC. Nucleotide sequence analysis of genome segment A of infectious bursal disease virus. J Gen Virol. 1990; 71: 569-577. doi: 10.1099/0022-1317-71-3-569

74. Escaffre O, Le Nouën C, Amelot M, et al. Both genome segments contribute to the pathogenicity of very virulent infectious bursal disease virus. J Virol. 2013; 87: 2767-2780. doi: 10.1128/ JVI.02360-12

75. Brown MD, Green P, Skinner MA. VP2 sequences of recent European 'very virulent' isolates of infectious bursal disease vims are closely related to each other but are distinct from those of 'classical' strains. J gen Virol. 1994; 75: 675-680. doi: 10.1099/00221317-75-3-675

76. Cao YC, Yeung WS, Law M, Bi YZ, Leung FC, Lim BL. Molecular characterization of seven Chinese isolates of infectious bursal disease vims: Classical,very virulent, and variant strains. Avian Dis. 1998; 42: 340-351. 